\title{
Carrying heavy backpacks and handbags amongst elementary students: Causes and solutions
}

\author{
Hossein Matlabi $^{1, ~}{ }^{*}$, Hamidreza Hamedi Behtash ${ }^{2}$, Ahmad Rasouli $^{2}$, Nasrin Osmani $^{2}$ \\ ${ }^{1}$ Dept of Health Education and Promotion, Faculty of Health Sciences, Tabriz University of Medical Sciences, Iran \\ ${ }^{2}$ Student Research Committee, Tabriz University of Medical Sciences, Tabriz, Iran

\section{Email address:} \\ matlabih@tbzmed.ac.ir (H. Matlabi)
}

\section{To cite this article:}

Hossein Matlabi, Hamidreza Hamedi Behtash, Ahmad Rasouli, Nasrin Osmani. Carrying Heavy Backpacks and Handbags Amongst Elementary Students: Causes and Solutions. Science Journal of Public Health. Vol. 2, No. 4, 2014, pp. 305-308.

doi: $10.11648 /$ j.sjph.20140204.20

\begin{abstract}
Backpack is the best type of bag for students as the weight of the pack is evenly distributed across the body. But backpacks that are overloaded or not used properly can make health problems. Injuries may occur when a child tries to balance for the extra weight by leaning forward, bending his or her back or leaning to the side. Over time this can cause the shoulders to become rounded and the upper back to become curved. Because of the heavy weight, there's a chance of developing shoulder, neck, and back pain. This study was conducted to determine the prevalence of heavy backpacks amongst elementary students. A case study was designed with participation of all students $(n=60)$ from first and fourth grade students. A researcher's constructed questionnaire was used to gather the required data. The weight of bag, the students' weight and ratio of load to body weight was measured and then assessed with standards issues. Several interviews were also conducted with teachers to interrogate the reasons of using heavy backpacks and possible solutions. The results showed that $87 \%$ of students carried a weight that is more than 10 percent of their body weight. Interestingly, first grade students' backpacks were heavier than fourth grade students' backpacks. It is recommended that the necessary facilities such as locker should be obtained to students in schools.
\end{abstract}

Keywords: Heavy Backpack, Primary Schools, Tabriz

\section{Introduction}

Among the social institutions, school is one of the most important formally organized institutions that by providing a healthy environment give the children's body and spirit ability to flourish [1].

The most common ways to take books, notebooks, and equipment which students need at school is bag or backpack. In other word backpacks are along with children during the school years and by using a backpack carry their equipment from home to school [2].

Backpack is the best type of bag for students. It divides the weight of the load into two parts. Backpacks that have a lumbar strap are even better because less pressure is put in [3]. The daily physical stresses associated with carrying backpacks cause significant forward lean of the head and trunk [4]. It is also suggested that load requirements for adult females should be lower than adult males to account for physiological and biomechanical differences [5].
Combined effects of heavy backpack, duration carrying the backpack, manipulating and handling of backpack, method of carrying, position of the load on the body of students are determinant factors for musculoskeletal complaints associated with backpack carriage [6,7].

Research findings show that backpacks with a strap cause asymmetry of the spine and disturbance in normal receptivity of hit by the spine and causing pain in shoulders, neck and back in children [8]. Some studies showed that many students were carrying bags that weighted significantly more than $10 \%$ of their bodyweight. A number of these students were actually carrying in excess of $20 \%$ of their bodyweight $[9,10,11]$. A general guideline of $10 \%$ body weight proposed by Voll et al. when carrying a schoolbag [12]. However, findings of recent studies may challenge this guideline [13].

Based on health care staff reports, most of pains or injuries in children were caused by carrying heavy backpacks and the incidence of back pain in early adolescence approaches that seen in adults [14]. 
Wilmarth, a member of sport medicine specialists' community, believes that heavy bag cause children's back pain, excessively stretch back, increase the children's lumbar dint and their posture deform, and causes lopsided and swept lumbar [15]. The results of a study conducted in an American college, unveiled that children's backpacks were too heavy in proportion to their weight. This study also showed that 55 percent of students carry the weight that is more than 15 percent of their body weight [15]. Furthermore, American Chiropractic Association believes that elementary school students should not carry more than $10 \%$ of their body weight $[16,17]$. Another Canadian study warns parents about side effects of heavy backpacks that children carry. Comparisons across load placements indicate that low load placement may minimize changes in posture and spinal curvature [18]. Other studies reported that back complaints more often occur in girl students [19, 20].

Despite the mentioned studies, in a survey, including 1376 children, Jones et al. [21] and Watson et al. [22] demonstrated the lack of significant association between low back pain and either the type of school bag, the method of carrying or the percentage of body weight carried.

The result of this study can be a good guide for health care staff in schools to teach proper use of bags, especially school backpacks for parents and students.

\section{Features of suitable bag based on scientific criteria:}

- Bags should be chosen from the lightest material:

- Top of the backpacks should not be higher than the shoulders and the bottom of that should not be lower than top of the hip bone:

- To avoid damaging to the spinal, backpacks should be used with two cords:

- Students should put heavier things close to the central axis of the body so that they get so close to the center of gravity of body:

- Students should avoid convoluting backpack on their back.

\section{Methods and Materials}

In order to investigate weight of school bag and its contents in association with students' weight, a case study was designed with participation of all students from first $(n=29)$ and fourth $(n=31)$ grade students in Khadija Kobra school in Tabriz, Iran. A researcher's constructed questionnaire was used to gather the required data. The weight of bag, the students' weight and ratio of load to body weight was measured and then was assessed with standards issues. In addition to measuring weight, the way of using backpack is also collected.

Backpacks were measured in early morning when the students usually didn't use their food. Then their weight was measured without shoes and jackets. After measuring the weight some questions were asked about way of using backpack and their standards for buying backpacks.

At the end, necessary training with educational pamphlets was given to the students. Several Interviews were also conducted with teachers $(n=5)$ to interrogate the reasons of using heavy backpacks and possible solutions.

\section{Results}

The first table shows that 90 percent of students take backpacks to school and 8.3 percent use hand bags and 1.66 percent use wheeled bags.

Table 1. Absolute and Relative Frequency Distribution of Students Depending on the Bag that Student Take to School

\begin{tabular}{lllllll}
\hline \multirow{2}{*}{ Type of bag } & \multicolumn{2}{l}{ First grade } & \multicolumn{2}{l}{ Fourth grade } & Total \\
& Count & PNT & Count & PNT & Count & PNT \\
\hline Backpack & 25 & 86.2 & 29 & 93.5 & 54 & 90 \\
Handbag & 3 & 10.3 & 2 & 6.4 & 5 & 8.3 \\
Other & 1 & 3.4 & 0 & 0 & 1 & 1.6 \\
Total & 29 & 100 & 31 & 100 & 60 & 100 \\
\hline
\end{tabular}

The second table shows that just 27.7 percent of students use one-side backpacks and 72.7 percent of students use two-side backpacks

Table 2. Distribution of Absolute and Relative Frequency of Students According to How to Use the Backpack (one-side or two-side)

\begin{tabular}{lllllll}
\hline \multirow{2}{*}{ Way of using } & \multicolumn{2}{l}{ First grade } & \multicolumn{2}{l}{ Fourth grade } & \multicolumn{2}{l}{ Total } \\
& Count & PNT & Count & PNT & PNT & PNT \\
\hline One- side & 5 & 20 & 10 & 34.4 & 15 & 27.7 \\
Two-side & 20 & 80 & 19 & 65.5 & 39 & 72.2 \\
Total & 25 & 100 & 29 & 100 & 54 & 100 \\
\hline
\end{tabular}

The third table shows that average weight of bags that first grade students take to school is $2.4 \mathrm{~kg}$ more than standard and average weight of bags that fourth grade students use is $0.5 \mathrm{~kg}$ more than standard. This shows that first grade students' backpacks are much heavier than the standard limit.

Table 3. Comparison of Average Weight of Backpacks Which Should Be Carried to School and Weight of Backpacks Which Practically

\begin{tabular}{llll}
\hline \multicolumn{1}{c|}{ Grade } & First grade & Fourth grade \\
\hline $\begin{array}{l}\text { Average weight of students } \\
\begin{array}{l}\text { Average weight of backpacks that } \\
\text { students should carry }\end{array}\end{array}$ & $24.1 \mathrm{Kg}$ & $35.4 \mathrm{Kg}$ \\
\begin{tabular}{l} 
Average weight of backpacks \\
\hline
\end{tabular} & $4.8 \mathrm{Kg}$ & $3.5 \mathrm{Kg}$ \\
\hline
\end{tabular}

\section{Discussion and conclusion}

There have been many studies that confirm the effects of back pain due to carrying heavy loads. Heavy backpack weight has been correlated with pain and musculoskeletal development. These conditions may require treatment and lead to lost school time among other things.

The findings of this research show that 87.30 percent of examined students take weight which is more than 10 percent of their body weight and among them 92 percent of 
students were first grade and 82 percent of them were fourth grade.

According to American Chiropractic Association, weight of elementary students' bags should be less than 10 percent of their body weight. By comparing the obtained data we can conclude that first grade students carry heavy bags. This outcome is also observed in a project which was done in Hamadan, Iran that indicates average weight of first grade students' bags is 200 gr more than second grade student's bags.

Many reasons can cause this problem. One of them can be related to their educational curriculum. First grade students usually take all their books to school and do not pay much attention to their curriculum. In this case parents should be taught to be careful about filling their child's bag.

Other reason for heaviness of bags is related to water bottles that all the students carry these full bottles of water. And they also put their further things like hat, and jacket into their bags. So students should be trained to fill their bottles up just before starting their classes and put their excess equipment in a handbag.

In this project it has been seen that 27.7 percent of students use one-side backpacks. In addition to their backpack's heaviness, way of carrying can also harm students' spine.

The findings show that health care workers in schools should train families about the weight of backpacks, way of carrying them and choosing them.

Furthermore, students should train to use both shoulder straps distributing the weight evenly. Wearing backpack on only one shoulder may cause them to lean to one side. In this way the head automatically leans forward, and this shifts the centre of gravity towards the neck to counterbalance the weight on the back. Kids carrying backpacks like to let the load hang down their back, which actually makes it harder to carry. They should shorten the shoulder strap, so that the load is ideally positioned between the shoulder and the middle of the back.

\subsection{Solutions}

According to results of interviews with teachers, finding suitable solutions to prevent these injuries seems necessary and these recommended solutions are divided into 3 parts that education officials and families should implement them.

\subsubsection{Educational facilities}

Undoubtedly suggestions and also implementations of every duty need time and expense such as:

- Preparing suitable lockers, cupboards with drawers or files and allocating each one of them to a student.

- In single-shift schools by educating students about not touching other's things, we can recommend them to put their belongings and books under benches and not to carry them to home.

- Holding educational classes by the subject of backpacks for families and providing educational brochures and distributing them among parents.
- Periodic examination of construction of students' stature by doctors and medical professionals.

- Dividing lesson topics of first semester from second semester into separated books.

- Matching the lessons which need additional books and notebooks with students' sport sessions.

\subsubsection{Family}

- $\quad$ Parents should proceed to buy the best kind of bags to students.

- $\quad$ Parents should supervise students in order not to carry unnecessary books and things to school so their backpack doesn't get heavy.

\subsubsection{Students}

- They should empty water bottles and fill them up before class.

- Not to carry unnecessary things and leave them at home, if it is necessary to carry excess things to school, they should put them in another bag.

- $\quad$ They should make effort to lighten their backpacks and not to carry unnecessary things to school.

- They should arrange their accessories in a way that the heaviest things get closer to their back.

- They should put their bag on their shoulders in a way that it be on the strongest mid-back muscles of their.

\section{Acknowledgments}

This project was done in partnership with staff and students of Khadija Kobra school in Tabriz, Iran. We would like to express our gratitude to all of them.

\section{References}

[1] Hoveidn H. Health statues of schools and students [Persian]. Translate: Hashtroudi A. Tehran: Chehr Publication; 1996

[2] Lasota A. Schoolbag weight carriage by primary school pupils. Work: A Journal of Prevention, Assessment and Rehabilitation. Accessed March 2013 Available from http://www.ncbi.nlm.nih.gov/pubmed/23531575

[3] Mohseni Kh. The best bag and its features [Persian]. Tehran: Soroush Educational Center; Tehran 2012.

[4] Mayank M, Upendar S, Nishat Q. Effect of backpack loading on cervical and shoulder posture in Indian school children. Indian J Physiotherapy Occupational Therapy. 2006; 1: 3-12.

[5] Haisman MF. Determinants of load carrying ability. Applied Ergonomics. 1988; 19: 111-121.

[6] Negrini S, Carabalona R. Schoolbags on! Schoolchildren's perceptions of load, associations with back pain and factors determining the load. Spine (Phila Pa 1976). 2002 Jan 15;27(2):187-95.Available http://www.ncbi.nlm.nih.gov/pubmed/11805666

[7] Puckree T, Silal S, Lin J. School bag carriage and pain in school children. Disabil Rehabil. 2004 Jan 7;26(1):54-9.

[8] Mahdi E. School's bag. Pain Journal. 2002; 20: 412-13. 
[9] Pascoe D, Pascoe DE, Wang YT, Shim D-M, Kim CK. Influence of carrying book bags on gait cycle and posture of youths. Ergonomics Volume 40, Issue 6, 1997 pages 631-640

[10] Shamsoddini AR, Hollisaz MT , Hafezi R . Backpack Weight and Musculoskeletal Symptoms in Secondary School Students, Iran J Public Health. 2010; 39(4): 120-125.

[11] Al-Hazzaa HM. School backpack. How much load do Saudi school boys carry on their shoulders? Saudi Med J. 2006 Oct;27(10):1567-71.

[12] Voll H, Klimt F. Strain in children caused by schoolbags. Offentl Gesundheitswes. 1977 Jul;39(7):369-78.

[13] Hong Y, Li J. Influence of load and carrying methods on gait phase and ground reactions in children's stair walking. Gait Posture. 2005 Aug;22(1):63-8.

[14] Skaggs DL, Early SD, D'Ambra P, Tolo VT, Kay RM. Back pain and backpacks in school children. $J$ Pediatr Orthop. 2006. 26(3):358-63.

[15] Wilmarth M. Dangerous effects of students' backpacks. [2007] Accessed May 2012 Available from: http://souri67.blogfa.com/page/mas13.aspx

[16] Maghami M. School backpacks and deformities of spines [Persian]. Sari: Tavana Rehabilitation Center; Accessed April 2012 April. Available from: http://tavanasari.blogfa.com/post-47.aspx
[17] Abedi A. Using backpacks are dangerous for students [Persian]. Accessed May 2012 Available from:

[18] Brackley HM, Stevenson JM, Selinger JC. Effect of backpack load placement on posture and spinal curvature in prepubescent children. Work: A Journal of Prevention, Assessment \& Rehabilitation 2009; 32(3):351-60.

[19] Balague F, Skovron ML, Nordin M, et al. Low back pain in schoolchildren: a study of familial and psychological factors. Spine (Phila Pa 1976). 1995 Jun 1;20(11):1265-70.

[20] Brattberg G. The incidence of back pain and headache among Swedish school children. Qual Life Res. 1994 Dec;3 Suppl 1:S27-31.

[21] Jones GT, Watson KD, Silman AJ, Symmons DP, Macfarlane GJ. Predictors of low back pain in British school children: A population-based prospective cohort study. Pediatrics 2003; 111:822-8.

[22] Watson KD, Papageorgiou AC, Jones GT, Taylor S, Symmons DPM, Silman AJ et al. Low back pain in school children: the role of mechanical and psychosocial factors. Arch Dis Child 2003; 88:12-7.

[23] Trousisier, Davoine P, de gaudemaris R, Fauconnier J Phelip $\mathrm{X}$. back pain in school children. Scandinavia Journal of Rehabilitation Medicine. 1994; 26:143-46. 